MA R Y NA A F A N A S I E V A, Postgraduate Department of Economic Analysis and Accounting National Technical University "Kharkiv Polytechnic Institute", 2, Kyrpychova St., Kharkiv, 61002, Ukraine

\title{
RISK ANALYSIS OF INEFFICIENCY AT UKRAINE'S MACHINE BUILDING ENTERPRISES *
}

The paper studies the annual public financial statements of 51 joint-stock machine building companies and the structural statistics of Ukraine in 2012-2017. The models of two types of risk coefficient have been proposed using proportion between the cost elements, as well as profit from the main operating activity in net turnover, and taking into account the importance of the value added indicator. We proved our working hypothesis that some companies which are risky according to economic analysis differ from others by variance and correlation analysis statistically significantly.

Keywords: control of efficiency; value added at factor cost; risk analysis; nonparametric analysis of variance; correlation analysis.

References 15; Tables 4; Figures 4; Formulas 7.

аспірант кафедри економічного аналізу та обліку Національного університету “Харківський політехнічний інститут”, вул. Кирпичова, 2, 61002, Харків, Україна

\section{АНАЛІЗ РИЗИКІВ НЕЕФЕКТИВНОСТІ НА УКРАЇНСЬКИХ ПІДПРИЯМСТВАХ МАІІИНОБУДУВАННЯ}

Розглянуто ідентифікацію ризиків неефективності на прикладах 51 українського акціонерного машинобудівного підприємства у 2012-2017 рр. Як результуючий показник ефективності обрано додану вартість за факторами виробництва (ДВ), яка є джерелом доходів різних соціальних груп, що сприяє консолідації ї зусиль. Щоб підтримати прогресивні технології та менеджмент, а не екстенсивне захоплення ринку, запропоновано мультиплікативну модель ДВ, де їі частка у випуску є оцінкою якісних процесів усередині підприємства. Проведено економічний аналіз щорічної публічної фінансової звітності та структурної статистики, щоб дослідити для основної операційної діяльності пропорції між елементами витрат в їх сумі та у зв'язку з прибутком у чистому доході від реалізації. $у$ результаті запропоновано моделі двох типів коефіцієнта ризику. Їх верифіковано за допомогою статистичного аналізу. Дані перевірено на дотримання закону нормального розподілу за тестом Шапіро - Уілка і на однорідність за коефіцієнтом кореляції. У ході непараметричного дисперсійного аналізу за тестом Крускала - Уоліса доведено, що групи ризику статистично значимо відрізняються від інших підприємств і один від одного. На підставі рангових коефіцієнтів кореляції Спірмена виявлено статистично значущу сильну і помірно сильну залежність показника ДВ/випуск від належності підприємства до

(C) Maryna Afanasieva (Афанасьєва Марина Анатоліївна), 2019; e-mail: marinaafanaseva911@gmail.com.

* The article was received in English, was reviewed on general grounds and printed in the authors presentation (стаття була надіслана англійською мовою, пройшла рецензування на загальних підставах і друкується в авторському викладі). 
групи ризику першого або другого типу. Виявлено, що 37\% підприємств вибірки є ризиковими, причому третина з них - це великі або середні компанії. Продемонстровано переваги методики порівняно з методом кластеризації Варда. Наша методика дозволяє виокремити більш вузьке коло проблемних підприємств. Зроблено висновок про те, що управлінські рішення щодо надання додаткових ресурсів варто перевіряти на предмет того, чи не є підприємство ризиковим за наданими алгоритмами. Для виправлення ситуації потрібно звертатися до концепції сталого розвитку.

Ключові слова: контроль ефективності; додана вартість за витратами виробництва; аналіз ризиків; непараметричний дисперсійний аналіз; кореляційний аналіз.

Бібл. 15; табл. 4; рис. 4; формул 7.

Efficiency is an important criterion for evaluating an enterprise. It should be taken into account when making decisions on investing private funds or choosing a business partner, allocating public resources to support a particular domestic producer and so on. Risks, including internal risks, are the enemies of efficiency. The capacity to recognize and confront the risks is a guarantee of sustainability for an enterprise [1] and the industry branch as a whole.

One of the key indicators of sustainable development is value added that is in one form or another applied for monitoring the performance of tasks related to the development of High and Middle High Tech manufacturing industries, innovative activities, real economy, medium and small-sized businesses [2]. Peter Drucker, one of the management gurus of the $20^{\text {th }}$ century, considered the value added to be a significant characteristic of an enterprise management system [3].

The purpose of this paper is to develop the risk detection tools, taking into account the importance of value added indicator.

The definition of value added at factor cost (VA) is provided in EU Regulation No. 250/2009. It is the gross income from operating activities after adjusting for operating subsidies and indirect taxes *. According to the Cornell University's Dictionary the gross income is the income of all persons earned from all sources before taxes. In other words, the question is about the total income of employees and entrepreneurs, which reflects the total contribution of labor and capital to VA that promotes coherence of interests of different social groups, which is a prerequisite for achieving of sustainable development.VA is calculated in all countries of the European Union according to the above Regulation; in Ukraine it is calculated according to the national methodology close to the European order **.

It is obvious that just effective entities have good perspectives and quality processes are more important than quantity ones: their use of modern technical and management technologies. In order to proceed to the assessment of quality processes, we have proposed a multiplicative two-factor model of VA (the resulting indicator) according to the following formula:

$$
\mathrm{VA}=\text { Output } \times \mathrm{VA} / \text { Output. }
$$

* EU Regulation No 250/2009 of 11 March 2009 implementing Regulation (EU) No 295/2008 of the European Parliament and of the Council as regards the definitions of characteristics, the technical format for the transmission of data, the double reporting requirements for NACE Rev.1.1 and NACE Rev.2 and derogations to be granted for structural business statistics, available at: http://eurlex.europa.eu/legal-content/EN/\%0bTXT/?qid=1415950264685\&uri=CELEX:02009R025020140520 (accessed 21.12.2018).

** Metodyka rozrakhunku pokaznyka strukturnoi statystyky "dodana vartist' za vytratamy vyrobnytstva" [Methodology for calculating the indicator of structural statistics "value added at factor cost”], the order dated January 19, No. 10. Kyiv: SSSU, 2016. 
We recall that a factor is a sign that characterizes the cause of a particular result. At that, output is generally a quantitative (extensive) factor, and the VA share is a qualitative (intensive) factor, which reflects the level of progressiveness of the technical and management technologies used by the enterprise. The important values of these indicators are both at present and in dynamics. Using formula (1) it is possible to determine whether the enterprise follows primarily extensive of intensive model of development and to conclude on the level of existing risks as well as future perspectives.

Then we proceed to creation of models for risk coefficients. As known there is the close relationship between VA and expenses and profit (here we consider only the main operating activity), so we apply economic analysis. The cost structure by economic elements has a certain rationale based on the proportions between materials and wages (Personnel costs), between wages and other operating expenses (Others). These relationships are also correlated with profit. Similar proportions are also used in such management practice as budgeting. This approach will be useful not only for machine building, but also for other branches, although the proportions are likely to be different.

In this study, the average value of the relevant indicators for the sample is taken as a basis for comparison. It is believed that the greater the deviation from the average (in both directions), the greater the probability of the enterprise being in the risk group.

Domestic industrial enterprises usually tend to have a closed production cycle with all necessary capacity; hence other operating expenses should be low. If the ratio of wages/materials is understated and others/wages is overstated compared with the average values for the group, then it is assumed that the risks increase with the decrease in profit. If the ratio of wages/materials is overstated (more than 1), then it is assumed that the risks increase with the decrease in profit. The explanations for the second option are as follows: if labor costs increase significantly while maintaining material costs at the same level, the natural consequence of this will be the decrease in profits; if the profit increases compared to the average values, this may be a sign that something is wrong. These two options form two risk groups, the first of which has understated VA/output, and the second has overstated ones, as will be shown in the third section. There is probability that risks of second type can be evoked thanks to wrong NACE (European activity classification) identification. In a formalized form, the conditions for the occurrence of risks are as follows:

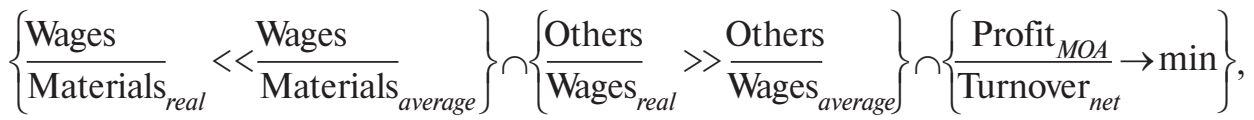

$$
\begin{aligned}
& \left\{\frac{\text { Wages }}{\text { Materials }_{\text {real }}}>1\right\} \cap\left\{\frac{\text { Profit }_{\text {MOA }}}{\text { Turnover }_{\text {net }}} \rightarrow \max \right\} \text {. }
\end{aligned}
$$

Let's start calculating risk coefficients. For the first option the mentioned relations were normalized taking into account the fact that wages/materials tend to the maximum (because wages in Ukraine are the lowest ones in Europe), and others/wages tend to the minimum (compared to the past personnel reduction for the period studied, it is natural to desire to replace the services of outside organizations with their own production).Then, according to financial analysis [4], the average ratio value in group for normalizing function $\mathrm{f}$ (wages/materials) will be maximal, and our attention will be paid to those subjects, the real ratio value of which is lower than the average. For normalizing function $f$ (others/wages) average ratio will be minimal, and our attention will be paid to those subjects, real ratio of which is higher than the average. Write it in such way:

$$
\max \mathrm{f}(\text { Wages } / \text { Materials })=\frac{\text { Wages } \text { Materials }_{\text {real }}}{\text { Wages }_{\text {Materials }} \text { average }},
$$




$$
\min \mathrm{f}(\text { Others/Wages })=\frac{\text { Others/Wages }_{\text {average }}}{\text { Others/Wages }_{\text {real }}} .
$$

If real values are, on the contrary, above average for wages/materials and below average for others/wages, they are assigned values equal to 1 . Since conditions concerning two relations must act simultaneously, the geometric average of two normalized values is calculated and subtracted it from 1. If the obtained interim result is adjusted for the specific weight of profit from main operating activity in net turnover, we will obtain the risk coefficients for enterprise of the first or second risk groups described above:

$$
\begin{gathered}
\mathrm{K}_{1}=1-\sqrt{\frac{\text { Wages/Materials }_{\text {real }}}{\text { Wages/Materials }_{\text {average }}} \times \frac{\text { Others/Wages }_{\text {average }}}{\text { Others/Wages }_{\text {real }}}}-\frac{\text { Profit }_{M O A}}{\text { Turnover }_{\text {net }}}, \\
\mathrm{K}_{2}=\frac{\text { Wages }_{\text {Materials }}^{\text {real }}}{\text { Turnover }_{\text {net }}} .
\end{gathered}
$$

where Wages/Materials and Others/Wages - the ratio of absolute costs or their specific weights in net cost; Profit ${ }_{M O A} /$ Turnover $_{\text {net }}$ - specific weight of profit from the main operating activity in turnover without VAT.

We use statistical analysis to verify our method for identifying high-risk enterprises [5]. Based on calculated risk coefficients, we divide our sample into three subgroups: a zero group where the risks are not obvious; risk group 1 with the risk of understated wages and profit and overstated other operating expenses; risk group 2 with the risk of overstated wages and profit. We put forward a working hypothesis that dependent variable (for instance, VA/Output share) is not evenly distributed in the sample, but differently in groups with different risk coefficients (grouping variable). Accordingly, the null hypothesis means that there is no difference between the selected groups, and they all belong to the same general population.

According to our calculations based on the structural statistics of Ukraine *, the VA share is significantly different for different types of machine-building, and for the period 2015-2016 it is as follows: NACE26 "Manufacture of computers, electronic and optical products" - 51\%, NACE27 "Manufacture of electrical equipment" - 29\%, NACE 28 "Manufacture of machinery and equipment" - 37\%, NACE 29 "Manufacture of motor vehicles" - 44\%, NACE 30 "Manufacture of other vehicles" - 47\% (NACE is relevant for Ukraine too). Therefore, this study is based on a homogeneous sample of 51 jointstock companies of Ukraine according to the basic NACE28 (Appendix A). The source of data for our calculations of VA and intermediate consumption - IC (that is the amount of material costs, which are equal to the costs of energy and the costs of outside services, consumed in the production; as is known, sum of IC and VA gives output) was the public financial statements of these companies, while other operating activity (for example, providing rental) was not taken into account (unlike official statistics).

The first efficiency probe can be the calculation and comparison of the basic increase indexes of VA and output over a period of time, for example, 2017 against 2012 (Figure 1): $77 \%$ of sample enterprises demonstrate increase in indicators, including $22 \%-1.5-2$ times, $14 \%-2-3$ times, $12 \%$ - more than three times. As we can see, they are not the same. If the VA index is greater than the output index (shown on the diagram above), this means an increase in the VA share for the studied period, and vice versa.

* Diyal'nist' sub'iektiv hospodariuvannia 2016 : statystychnyi zb. [Activity of economic entities in2016 : statistical collection]. Kyiv: SSSU, 2017, available at: www.ukrstat.gov.ua (accessed 04.12.2018). 


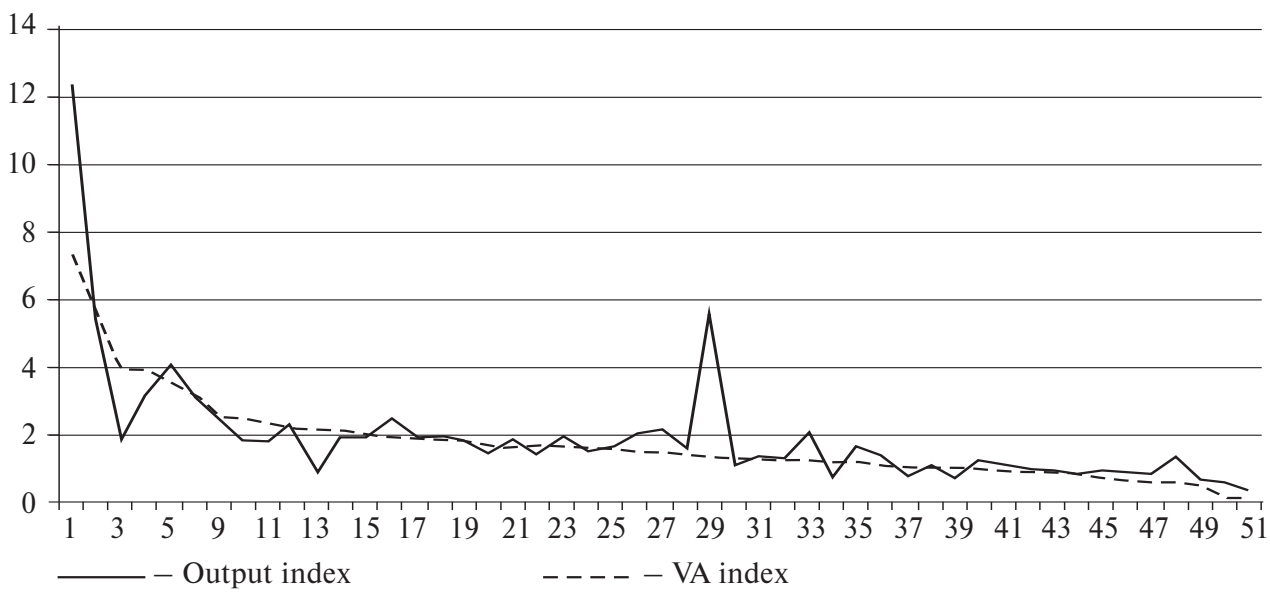

Fig. 1. VA and output indexes 2017 against 2012

(Co. names corresponding to rating no. are in Appendix)

Source: developed by author on basis of annual public financial reports of Co. from: The Ukrainian SMIDA. Official site of Ukrainian Stock market infrastructure development agency, available at: https://smida.gov.ua (accessed 12.02.2019).

The greatest differences between these two indexes are observed for four enterprises: enterprises No. 1/19 and 29/30 (rating/base numbers: company names corresponding to rating and base no. are proved in appendix) show a considerable increase in output with a much smaller increase in VA, that is, with a significant drop in the VA/output share, which indicates an extensive market capture; and enterprises No. $3 / 14$ and 13/15 show a considerable increase in VA with a much smaller increase in output, that is, with an increase in the VA/output share, which may be a consequence of the intensive development of these enterprises. It is likely that enterprises No. 14 and 15 that produce capital goods for large companies find it more difficult to compete for sales markets under conditions of change. Based on these data, the management decision may be the refusal to provide additional resources to enterprises No. 19 and 30 in favor of enterprises No. 14 and 15 . Generally, the output and VA indices for the groups for these two years were as follows: for NACE $28-1.27$ and 1.33; for the sample -1.31 and 1.25 , that is, joint-stock companies show somewhat worse dynamics of quality indicators. Micro-macro researches are considered as up to day approach to solving complicated problems [6].

A more detailed analysis for all the intervals of the period is required for more reasonable conclusions (for example, see Figure 2). On own calculating, magnitudes of VA share for International Corporation DMG MORI is 39\% in 2016-2017, that is comparable with last indicator values of companies No. 14, 15 and is not with entities No. 19, 30 [7]. So, in this case it is appropriate to leave the management decision mentioned above. There is a rule in Ukraine by which $20 \%$ of the purchase price of domestic agricultural equipment is returned to the buyer at the expense of the budget. Obviously it should be supplemented by the condition of compliance with certain performance criteria (VA/output) by the producer.

Then we identify high-risk enterprises on the basis of two proposed models. Due to instability of majority of indicators in time, it was decided to average variables over five years to minimize accidents and highlight more stable trends for each respondent. We have calculated the specific costs by economic elements, their ratio and risk coefficients under formulas 6, 7 (Table 1). It has been found that $37 \%$ of the sample enterprises are in the risk groups. In $2017 \mathrm{VA} /$ output indicator becomes noticeably better only for two risk entities: No. 21, 26; it becomes much worse for five risk companies: No. 30, 19, 5, 44, and 2. 

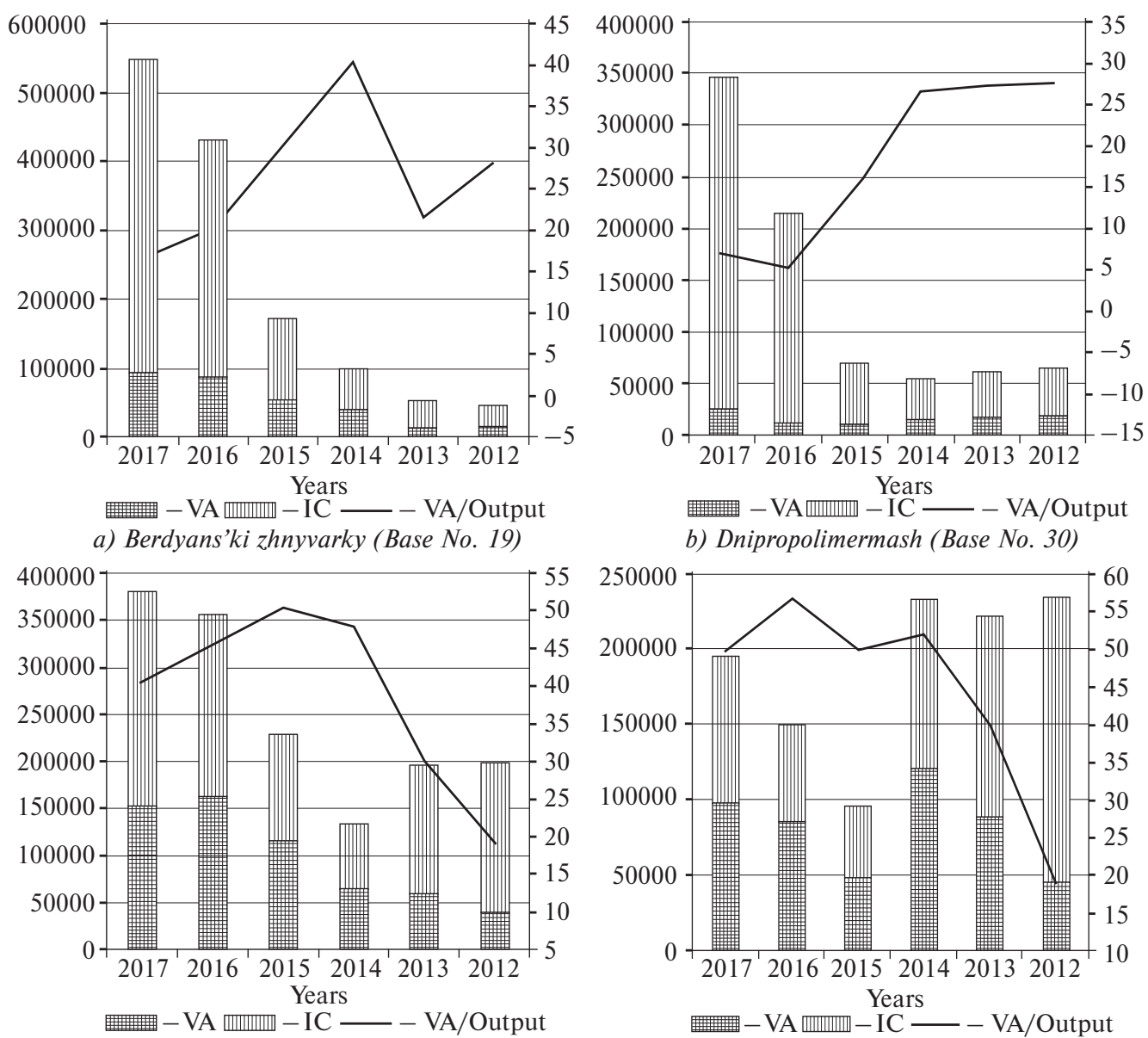

c) Zaporiz'kyi z-d vazhkoho kranobuduvannya (No. 14) d) Kramators'kyi z-d vazhkoho verstatobuduvannya (No. 15)

Fig. 2. Dynamics of VA, IC, output (UAH thou.) and share VA/output (\%) for four companies Source: developed by author on basis of annual public financial reports of Co. from: The Ukrainian SMIDA. Official site of Ukrainian Stock market infrastructure development agency, available at: https://smida.gov.ua (accessed 12.02.2019).

Table 1

Risk coefficients, specific costs by economic elements, VA share in 2012-2016 against 2017

\begin{tabular}{|c|c|c|c|c|c|c|c|c|c|c|c|c|c|c|}
\hline \multirow{2}{*}{ Indicator $(\%)$} & \multicolumn{14}{|c|}{ Co no. (company names corresponding to base no. are in Appendix) } \\
\hline & 30 & 32 & 19 & 21 & 18 & 27 & 5 & 44 & 35 & 2 & 14 & 6 & 42 & 9 \\
\hline Risk coef. $K_{1}$, unit & 0,78 & 0,66 & 0,65 & 0,60 & 0,51 & 0,48 & 0,48 & 0,40 & 0,34 & 0,33 & 0,30 & 0,30 & 0,27 & 0,25 \\
\hline Cost of materials & 73 & 57 & 65 & 71 & 65 & 71 & 66 & 32 & 76 & 43 & 64 & 67 & 51 & 66 \\
\hline Other op. expenses & 9 & 7 & 24 & 14 & 15 & 15 & 12 & 21 & 5 & 24 & 12 & 11 & 17 & 4 \\
\hline Personnel costs & 8 & 12 & 9 & 15 & 16 & 10 & 20 & 42 & 16 & 31 & 17 & 21 & 27 & 28 \\
\hline Depreciation & 9 & 6 & 3 & 1 & 3 & 4 & 2 & 4 & 3 & 2 & 8 & 1 & 5 & 2 \\
\hline Profit of MOA & -3 & 7 & 17 & 2 & 8 & 28 & -6 & -23 & 1 & 1 & 12 & 8 & -2 & -14 \\
\hline $\begin{array}{l}\text { VA/Output } \\
2012-2016\end{array}$ & 15 & 24 & 26 & 17 & 26 & 38 & 17 & 35 & 20 & 33 & 39 & 28 & 31 & 20 \\
\hline VA/Output 2017 & 7 & 30 & 17 & 25 & 28 & 36 & 8 & 22 & 20 & 16 & 41 & 26 & 24 & 25 \\
\hline \multirow{2}{*}{ Indicator (\%) } & \multicolumn{14}{|c|}{ Co no. (company names corresponding to base no. are in Appendix) } \\
\hline & 50 & & 24 & 51 & 3 & 3 & 26 & & 44 & 41 & & $\mathrm{X}$ & & ample \\
\hline Risk coef. $\mathbf{K}_{2}$, unit & 1,79 & & 54 & 1,51 & 1 , & 30 & 1,24 & & ,08 & 1,01 & & $\mathrm{X}$ & & $X$ \\
\hline Cost of materials & 35 & & 41 & 35 & 3 & 9 & 41 & & 32 & 49 & & $X$ & & 56 \\
\hline Other op. expenses & 1 & & 0 & 8 & 1 & 0 & 6 & & 21 & 0 & & $X$ & & 10 \\
\hline Personnel costs & 63 & & 55 & 53 & 4 & 4 & 49 & & 42 & 48 & & $\mathrm{X}$ & & 29 \\
\hline
\end{tabular}


The end of the table

\begin{tabular}{|l|c|c|c|c|c|c|c|c|c|}
\hline Depreciation & 1 & 4 & 4 & 7 & 3 & 4 & 3 & $\mathrm{X}$ & 5 \\
\hline Profit of MOA & 1 & 18 & -3 & 19 & 5 & -23 & 4 & $\mathrm{X}$ & 6 \\
\hline VA/Output & & & & & & & & & \\
2012-2016 & 64 & 66 & 56 & 60 & 55 & 35 & 53 & $\mathrm{X}$ & 38 \\
\hline VA/Output 2017 & 62 & 67 & 62 & 64 & 39 & 22 & 54 & $\mathrm{X}$ & 37 \\
\hline
\end{tabular}

Source: calculated by author on basis of annual public financial reports of Co. from: The Ukrainian SMIDA. Official site of Ukrainian Stock market infrastructure development agency, available at: https://smida.gov.ua (accessed 12.02.2019).

To verify the differences between the selected subgroups of sample, we use statistical analysis of the specific elements of costs and specific components of sales, including profit, as well as VA/output share and the absolute values of output and VA. We have performed all calculations in STATISTICA Microsoft. First, we checked the data submission to the normal distribution law by the Shapiro - Wilk test [8]. For indicators that do not correspond to the normal distribution (p-level in fact less 0.00070), the coefficients of variation are calculated, which exceed $60 \%$ and display the heterogeneity of the data (their variance) (Table 2).

Coefficients of variation $(\mathrm{CV}, \%)$ of specific indicators in 2012-2016

Table 2

\begin{tabular}{|l|c|l|c|l|c|l|c|}
\hline \multicolumn{1}{|c|}{ Indicator } & CV & \multicolumn{1}{c|}{ Indicator } & CV & \multicolumn{1}{|c|}{ Indicator } & CV & \multicolumn{1}{c|}{ Indicator } & CV \\
\hline Output (abs.) & 177 & VA (abs.) & 205 & Administrative & 68 & Sales expenses & 69 \\
\hline Profit & 223 & Wages & 44 & Depreciation & 79 & Other op. expenses & 81 \\
\hline
\end{tabular}

Source: calculated by author on basis of annual public financial reports of Co. from: The Ukrainian SMIDA. Official site of Ukrainian Stock market infrastructure development agency, available at: https://smida.gov.ua (accessed 12.02.2019).

Non-conformity of some data with the normal distribution and their heterogeneity suggest the need for further use of nonparametric statistical analysis. It is based on ranking data, when, instead of actual values, they work with ranks of ordered observable data; it allows over coming above mentioned restrictions [9].

Then, we apply Kruskal - Wallis test (ANOVA by ranks) to simultaneously compare several independent groups [10]. The results are interpreted on the basis of the p-level (the error probability to discard the null hypothesis): if it is less than 0.05 for $95 \%$ confidence, the differences are considered statistically significant, and the working hypothesis is true. To the contrary, if the p-level is greater than 0.05 , then the null hypothesis is true. In Table 3, the variables are arranged in descending order from factor, where the VA/output and the wages are statistically significantly different for all possible group comparisons (the maximum number of such comparisons in our case is three); other operating expenses are statistically significantly different for group 1 and each of other two groups; material costs - for group 2 and each of other two groups (that is, in two of the three possible cases). It is obvious that it is necessary to strengthen control of these indicators: for group 1 - wages and others, and for group 2 - wages and materials.

Table 3

Results of Kruskal - Wallis test with risk type as grouping variable in 2012-2016

\begin{tabular}{|c|c|c|c|c|c|c|c|}
\hline \multicolumn{8}{|c|}{ p-level } \\
\hline \multirow{2}{*}{\multicolumn{4}{|c|}{$\begin{array}{c}\text { Average VA / Output share } \\
\text { Kruskal - Wallis test: } \mathrm{H}(2, \mathrm{~N}=51)=30,60961 \mathrm{p}=, 0000\end{array}$}} & \multirow{2}{*}{\multicolumn{4}{|c|}{$\begin{array}{c}\text { Average specific Personnel costs } \\
\text { Kruskal - Wallis test: } \mathrm{H}(2, \mathrm{~N}=51)=25,11781 \mathrm{p}=, 0000\end{array}$}} \\
\hline & & & & & & & \\
\hline & 0 - R:28,774 & 1 - R:10,214 & 2 - R:48,500 & & 0 - R:27,677 & $1-\mathrm{R}: 12,714$ & $2-\mathrm{R}: 48,333$ \\
\hline $\mathbf{0}$ & & 0,000317 & 0,008788 & $\mathbf{0}$ & & 0,005319 & 0,005512 \\
\hline 1 & 0,000317 & & 0,000000 & 1 & 0,005319 & & 0,000003 \\
\hline 2 & 0,008788 & 0,000000 & & 2 & 0,005512 & 0,000003 & \\
\hline
\end{tabular}


The end of the table

\begin{tabular}{|c|c|c|c|c|c|c|c|}
\hline \multicolumn{4}{|c|}{$\begin{array}{l}\text { Average specific other operating expenses } \\
\text { Kruskal - Wallis test: } \mathrm{H}(2, \mathrm{~N}=51)=16,12677 \mathrm{p}=, 0003\end{array}$} & \multicolumn{4}{|c|}{$\begin{array}{c}\text { Average specific cost of materials } \\
\text { Kruskal - Wallis test: } \mathrm{H}(2, \mathrm{~N}=51)=14,81176 \mathrm{p}=, 0006\end{array}$} \\
\hline & 0 - R:21,742 & 1 - R:39,357 & 2 - R:16,833 & & $0-\mathrm{R}: 26,194$ & 1 - R:34,071 & $2-\mathrm{R}: 6,1667$ \\
\hline 0 & & 0,000700 & $* 1,000$ & $\mathbf{0}$ & & $* 0,299$ & 0,007572 \\
\hline 1 & 0,000700 & & 0,005707 & 1 & $* 0,299$ & & 0,000359 \\
\hline 2 & $* 1,000$ & 0,005707 & & 2 & 0,007572 & 0,000359 & \\
\hline
\end{tabular}

Source: own calculation.

* Differences are not statistically significant.

Box-and-whisker plots are shown below: medians, 25-75\% quartiles and minimum and maximum for four variables, which illustrate the above mentioned differences between groups well (Figure3). That is the distinguished groups of enterprises are statistically significantly different and our working hypothesis is true.
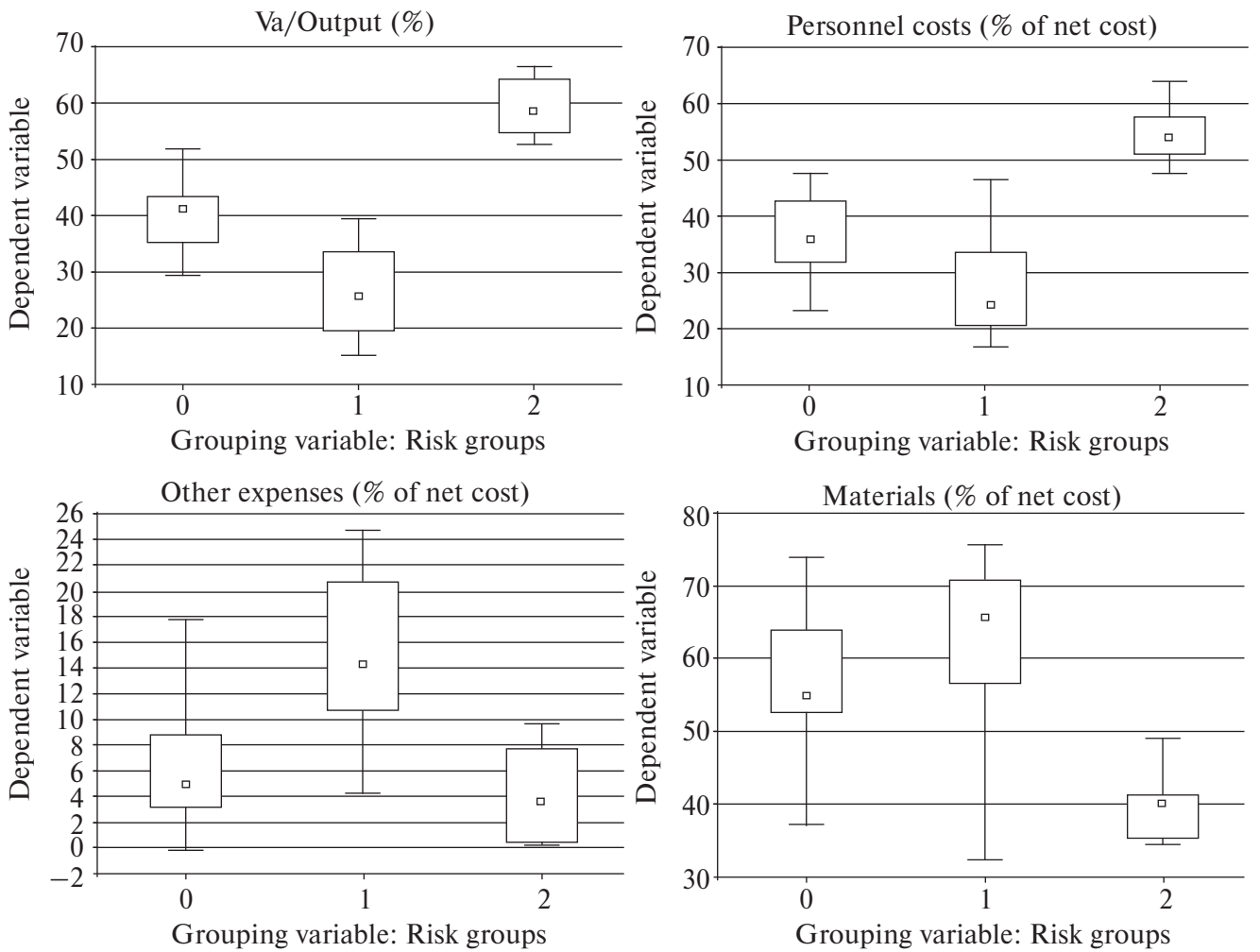

Fig. 3. Box-and-whisker plots of four indicators (average values in 2012-2016)

by three risk groups: $\mathbf{0}$ - risks are not obvious, 1 - low wages and profits and high other operating expenses, 2 - high wages and profit.

Source: developed by author.

To confirm the quality of our method for identifying risk enterprises, the Spearman's rank correlation coefficients [11] between chosen indicators and belonging to a certain risk group were calculated (Table 4). The values of it are within the range from -1 to +1 , where the values equal to 0.3 or less are considered evidence of weak relation, the values greater than 0.4 , but less than 0.7 - evidence of moderate relation, and the values of 0.7 and greater - evidence of high relation.

As you can see, the statistically significant strong and moderately strong dependences of the VA/output share on belonging of the enterprise to risk group 1 or 2 were found: the 


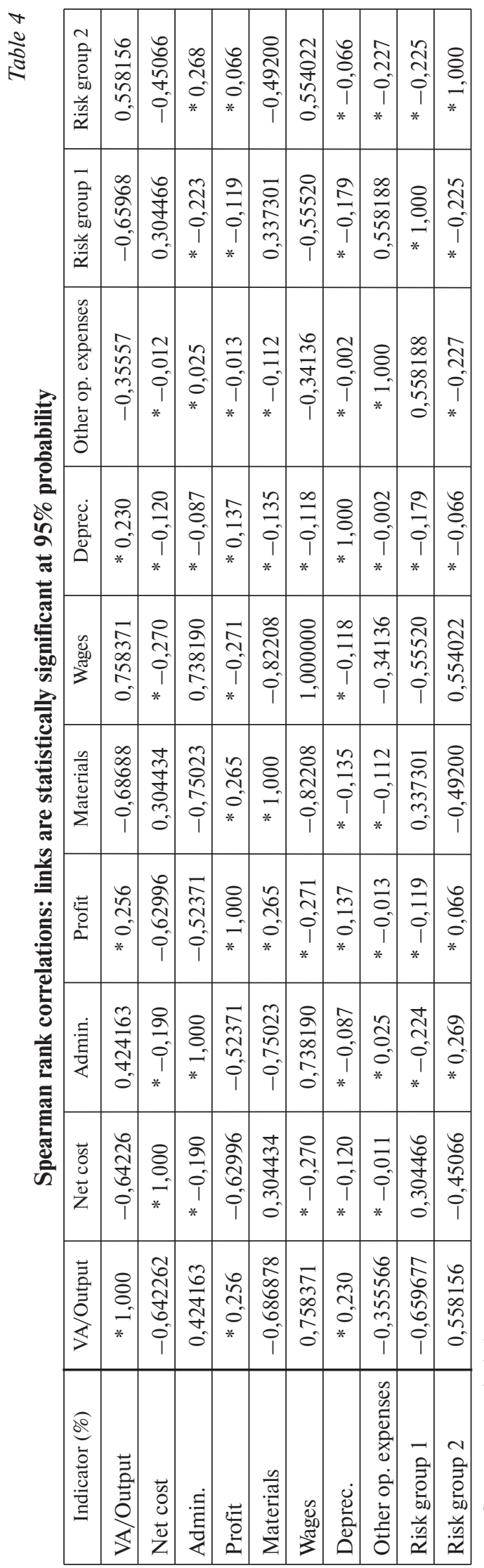

Spearman's correlation coefficients are minus 0.66 and 0.56 respectively. Similar dependencies are noted for indicators of wages, other operating expenses, material costs and net cost. The strongest correlation was found for specific wages and materials cost $(-0.82)$, and the weak connection between wages and other operating expenses $(-0.34)$. Additional factors that affect the VA/output share are as follows in decreasing order: wages (0.76), materials $(-0.69)$, other operating expenses $(-0.36)$. Probably relation to worker as a person plays most important role in improving quality processes in production. Attention is also drawn to the strong dependence of wages and administrative costs (0.74), which may be evidence of a case when the administration receives substantial wages and the production staff receives either humble wages or shadow wages.

In the end let's to compare our method of dividing the sample into subgroups according to risk degree with the Ward's clustering method without grouping variable, where the Euclidean distance is a proximity measure of elements [12; 13], and each enterprise characterizes the above set of indicators (Figure 4). Generally, the method is quite effective, but it creates clusters of small size, and, consequently, a large number of them. But our task $\ddot{H}$ among other things is to distinguish a limited number of enterprises with the $\frac{5_{0}}{\sigma}$ largest risk coefficients due to the fact त. that control must be effective and, therefore, economical. In addition, clustering is carried out at a formally chosen distance, which does not take into account the possible transitions of quantity into quality.

As you can see, there are three large clusters at a distance of 120, 102 and 78 (we'll call them group A, B and C), which can be compared with our 
risk groups 1, 2, 0, given that more risky groups correspond to large heterogeneity and, therefore, long Euclidean distances between elements. Indeed, $90 \%$ of the enterprises identified by our method are included in the Ward A and B groups, and only two enterprises out of twenty, No. 2 and 42, are not. The Ward A and B groups include 10 more enterprises that we do not classify in such way. That is, our method is consistent with Ward's one and complements it: it allows to associate a Ward's diagram with a certain economic substance and to distinguish a narrow range of problem enterprises. So, when making management decisions on the enterprise evaluation, we should check whether it is not risky according to the proposed algorithms.

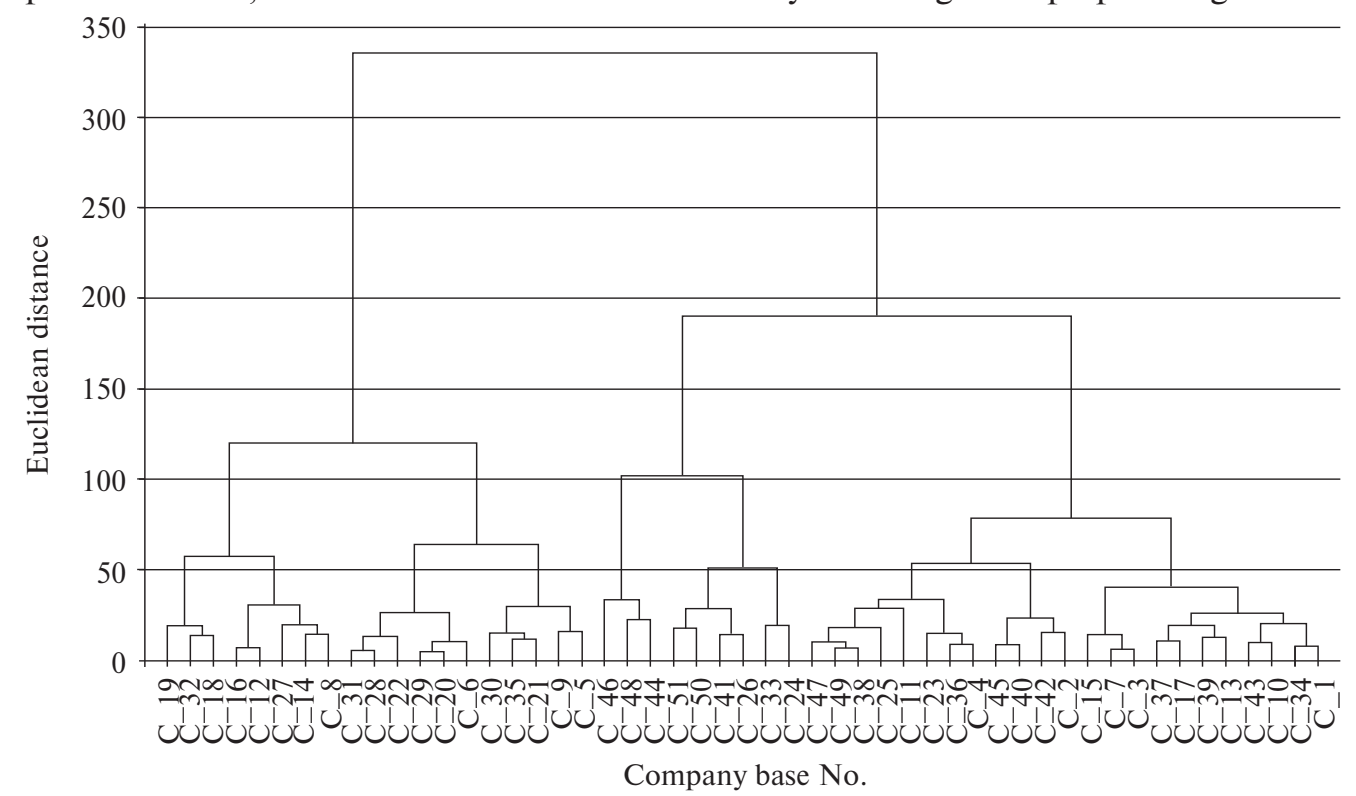

Fig. 4. Ward's dendogram of clusters of sample enterprises

Source: developed by author.

\section{Conclusion}

Determination of efficiency on the basis of value added at factor cost takes into account the interests of three main groups of society: entrepreneurs, citizens represented by employees and the state, which contributes to combined efforts and sustainable development. To support advanced production and management technologies the multiplicative model of VA with share of it in output has been proposed. It all owsperforming quantitative assessment the quality processes within the enterprise. Based on it the economic analysis has been conducted to deduce which companies have primarily extensive or intensive development.

The method of identifying enterprises with high-risk based on complying with the proportions between the cost elements, as well as the profit from main operating activity rate, has been suggested. The results have been verified by nonparametric statistical analysis: Kruskal Wallis variance test and Spearman correlation coefficients. Statistically significantly differences between risk groups have been found. Advantages of the method in comparison with the Ward clustering were presented. So, the paper provides tools for risk detection.

The results of this study highlight that $37 \%$ of the sample enterprises are risky, and a third of this is the large and medium-sized companies. There are cases of extensive capture of market, when output rises along with a very low VA share.

These results might have the biggest concern on the business that should make substantial efforts to improve the performance management system including control. It 
needs risk-response to relevant comments. On the other hand Ukraine is characterized by a large share of shadow economy, which demonstrates that erroneous values are widespread in the society.

In this environment a role of external monitoring and financial analysis should grow, such as independent audit, state and civil control [14].

To overcome the identified risks it is suggested to refer to sustainable development concept that provides genuine values, goals, ways and recommendations for business and other social groups to achieve their best. It includes compliance with legislation, professional opinions and ethics, as well as increasing people participation, promoting persons contributing to improvement [15].

\section{References}

1. Dmytrenko I.M. Kontseptsiya Rozvytku Audytu Korporatyvnykh System [The Concept of Development of Corporate Systems' Audit]. Kyiv, "Kondor-PH” Ltd, 2013 [in Ukrainian].

2. Vlasenko N. Pokaznyky dlya Monitorynhu Stanu Dosyahnennya Tsilei Staloho Rozvytku: Metodolohiya Zboru ta Rozrakhunku Danykh. Analit. zvit v ramkakh proektu PROON/GEF “Integratsiya Polozhen' Konventsii Rio u Natsional'nu Polityku Ukrainy” [Indicators for Monitoring the Status of Achievement of the Sustainable Development Goals: a Methodology for the Data Collecting and Calculating. Analytical report within the "Integrating Rio Convention Provisions Ukraine's National Policy Framework" UNDP/GEF project]. Kyiv, 2017 [in Ukrainian].

3. Drucker P. Management Challenges for the 21st Century. New York, HarperBusiness, 2001.

4. Bilyk M.D., Pavlovs'ka O.V., Prytulyak N.M., Nevmerzhyts'ka N.Yu. Finansovyi Analiz [Financial Analysis]. Kyiv, KNEU, 2007 [in Ukrainian].

5. Siegel A. Practical Business Statistics. New York, University of Washington, Irwin McGraw-Hill, 2000.

6. Molina-Azorin J.F. Micro foundations of strategic management: toward micromacro research in the resource-based theory. Business Research Quarterly, 2014, Vol. 17, Iss. 2, pp. 102-114, available at: https://www.sciencedirect.com/science/article/pii/ S2340943614000206?via\%3Dihub. DOI: http://dx.doi.org/10.1016/j.brq.2014.01.001.

7. Afanasieva M.A. Udoskonalennya form finansovoi zvitnosti yak krok na shlyakhu do staloho rozvytku [Improving the forms of financial reporting as a step towards sustainable development]. Proceedings from: Oblik, kontrol' $i$ analiz $v$ upravlinni pidpryemnyts'koyu diyal'nistyu. 6-a Vseukrains'ka nauk.-prakt. internet-konf., 28 bereznya 2018. U 2 ch. [Accounting, control and analysis in the management of entrepreneurial activity. 6th AllUkrainian Scientific and practical Internet conference. March 28, 2018. In 2 parts]. Vinnytsya, VITE KNUTE, 2018, Part 1, pp. 8-12 [in Ukrainian].

8. Shapiro S., Wilk M. An analysis of variance test for normality. Biometrics, 1965, Vol. 52, No. 3, pp. 591-611.

9. Corder G., Foreman D. Nonparametric Statistics: A Step-by-Step Approach. New Jersey, Wiley, 2014.

10. Kruskal W.H., Wallis W.A. Use of ranks in one-criterion variance analysis. Journal of the American Statistical Association, 1952, Vol. 47, No. 260, pp. 583-621.

11. Spearman C. The proof and measurement of association between two things. American Journal of Psychology, 1904, Vol. 15, pp. 72-101, available at: https://www.jstor. org/stable/1412159?origin=crossref\&seq=1\#metadata_info_tab_contents. DOI: http:// dx.doi.org/10.2307/1412159. 
12. Ward J. Hierarchical grouping to optimize an objective function. Journal of the American Statistical Association, 1963, Vol. 58, pp. 236-244.

13. Reiff M., Tokar V. Post-communist financial and economic development: cluster analysis of selected countries. Economic Annals-XXI, 2016, Vol. 161 (9-10), pp. 12-17, available at: http://soskin.info/userfiles/file/Economic-Annals-pdf/DOI/ea-V16103.pdf. DOI: https://doi.org/10.21003/ea.V161-03.

14. Afanasieva M.A. Economic control by civil society: an institutional approach. available at: http://www.economukraine.com.ua/index.php?id=17607\&show=86402.

15. Afanasieva M.A. Kontseptsiya staloho rozvytku ta ii korysnist' dlya rozrobky mekhanizmu kontrolyu $v$ systemi upravlinnya pidpryemstvom [Sustainable development concept and its usefulness for development of economic control mechanism in management of enterprise]. Efektyvna ekonomika - Effective economy, 2018, No. 11, available at: http://www.economy.nayka.com.ua/?op=1\&z=6713. - DOI: 10.32702/2307-21052018.11.206 [in Ukrainian].

\section{Список використаної літератури}

1. Дмитренко I.M. Концепція розвитку аудиту корпоративних систем : моногр. - К. : ТОВ “Кондор-Видавництво”, 2013. - 364 с.

2. Власенко Н. Показники для моніторингу стану досягнення Цілей сталого розвитку: методологія збору та розрахунку даних : аналіт. звіт в рамках проекту ПРООН/ГЕФ “Інтеграція положень Конвенцій Ріо у національну політику України”. - К., 2017. - 232 с.

3. Друкер П. Задачи менеджмента в XXI веке ; [пер. с англ.]. - М. : Вильямс, 2007. -272 c.

4. Білик М.Д., Павловська О.В., Притуляк Н.М., Невмержицька Н.Ю. Фінансовий аналіз : навч. посіб. - К. : КНЕУ, 2007. - 592 с.

5. Сигел Э. Практическая бизнес-статистика ; [пер. с англ.]. - М. - СПб. - К. : Вильямс, 2002. - $1056 \mathrm{c.}$

6. Molina-Azorin J.F. Micro foundations of strategic management: Toward micromacro research in the resource-based theory // Business Research Quarterly. - 2014. Vol. 17. - Iss. 2. - P. 102-114. - DOI: http://dx.doi.org/10.1016/j.brq.2014.01.001.

7. Афанасьєва М.А. Удосконалення форм фінансової звітності як крок на шляху до сталого розвитку / Облік, контроль і аналіз в управлінні підприємницькою діяльністю : зб. наук. праць 6-ї Всеукраїнської наук.-практ. інтернет-конф., 28 березня 2018. - У 2 ч. - Вінниця : ВТЕI КНТЕУ, 2018. - Ч. 1. - С. 8-12.

8. Shapiro S., Wilk M. An analysis of variance test for normality // Biometrics. 1965. - Vol. 52. - No 3. - P. 591-611.

9. Corder G., Foreman D. Nonparametric Statistics: A Step-by-Step Approach. New Jersey : Wiley. - 2014. - 267 p.

10. Kruskal W.H., Wallis W.A. Use of ranks in one-criterion variance analysis // Journal of the American Statistical Association. - 1952. - Vol. 47. - No. 260. - P. 583-621.

11. Spearman $C$. The proof and measurement of association between two things // American Journal of Psychology. - 1904. - Vol. 15. - P. 72-101. - DOI: http://dx.doi. org/10.2307/1412159.

12. Ward J. Hierarchical Grouping to Optimize an Objective Function // Journal of the American Statistical Association. - 1963. - Vol. 58. - P. 236-244.

13. Reiff M., Tokar V. Post-communist financial and economic development: cluster analysis of selected countries // Economic Annals-XXI. - 2016. - Vol. 161 (9-10). P. 12-17. - DOI: https://doi.org/10.21003/ea.V161-03. 
14. Afanasieva M.A. Economic control by civil society: an institutional approach. available at: http://www.economukraine.com.ua/index.php?id=17607\&show=86402.

15. Афанасьєва М.А. Концепція сталого розвитку та їі корисність для розробки механізму контролю в системі управління підприємством // Ефективна економіка. - 2018. - № 11 [Електронний ресурс]. - Режим доступу : http://www.economy.nayka.com.ua/?op=1\&z=6713. - DOI: 10.32702/2307-2105-2018.11.206.

\section{Appendix. List of machine building plants of sample}

\begin{tabular}{|c|c|}
\hline \multicolumn{2}{|c|}{ Base (rating) no. and short name of JSC [main type of goods] } \\
\hline $\begin{array}{l}1 \text { (19). Novokramators'kyi mashynobudiv- } \\
\text { nyi z-d } \\
2 \text { (51). Sums'ke mashynobudivne SPA } \\
3 \text { (20). Sums'kyi z-d nasosenerhomash } \\
\text { [pumps] } \\
4 \text { (49). Dniprovazhmash } \\
5 \text { (50). Kryvoriz'kyi z-d hirnychoho oblad- } \\
\text { nannya [mining equipment] } \\
6 \text { (47). OTIS Kyiv [lifts] } \\
7 \text { (40). Svitlo shakhtarya Kharkiv [mine } \\
\text { equipment] } \\
8 \text { (5). El'vorti Kropyvnyts'kyi [agricultural } \\
\text { machinery] } \\
9 \text { (32). Kharkivs'kyi traktornyi z-d [tractors] } \\
10 \text { (23). Kremenchuts'kyi z-d dorozhnikh } \\
\text { mashyn [road machines] } \\
11 \text { (37). Kharkivs'kyi pidshypnykovyi z-d } \\
\text { [bearings] } \\
12 \text { (21). Hidrosyla Kropyvnyts'kyi } \\
13 \text { (42). Poltavs'kyi turbomekhanichnyi z-d } \\
14 \text { (3). Zaporiz'kyi z-d vazhkoho kra- } \\
\text { nobuduvannya [heavy cranes] } \\
15 \text { (13). Kramators'kyi z-d vazhkoho versta- } \\
\text { tobuduvannya } \\
16 \text { (4). Hidrosyla APM [agricultural } \\
\text { machinery] } \\
17 \text { (17). Dnipropetrovs'kyi z-d prokatnykh } \\
\text { valkiv [rollers] } \\
18 \text { (24). Karlivs'kyi mashynobudivnyi z-d } \\
\text { [agricultural machinery] } \\
19 \text { (1). Berdyans'ki zhnyvarky [harvesters] } \\
20 \text { (6). Romens'ka traktorozapchastyna } \\
\text { [tractor parts] } \\
21 \text { (11). Konekreins Odesa Ukraina }\end{array}$ & $\begin{array}{l}22 \text { (35). Uman'fermmash [agricultural machinery] } \\
23 \text { (36). Kompresormash URI Sumy [compressors] } \\
24 \text { (9). Khorol's'kyi mekhanichnyi z-d } \\
25 \text { (38). Slov'yans'kyi mashynobudivnyi z-d } \\
26 \text { (27). Berdychivs'kyi Prohres } \\
27 \text { (2). Bohuslavs'ka sil'hosptekhnika [agricultural } \\
\text { machinery] } \\
28 \text { (14). Hidrosyla MZTH [hydraulic pumps] } \\
29 \text { (15). Bars'kyi mashynobudivnyi z-d } \\
30 \text { (29). Dnipropolimermash } \\
31 \text { (10). Beryslavs'kyi mashynobudivnyi z-d } \\
32 \text { (34). Korostens'kyi z-d khimichnoho mashynobudu- } \\
\text { vannya } \\
33 \text { (39). Sves'kyi nasosnyi z-d Sumy [pumps] } \\
34 \text { (46). Melitopol's'kyi kompresor } \\
35 \text { (16). Hidrosyla LYeDA [hydraulic pumps] } \\
36 \text { (41). Interkondytsioner Kharkiv } \\
37 \text { (25). Mohyliv-Podil's'kyi mashynobudivnyi z-d } \\
38 \text { (26). Poltavs'kyi mashynobudivnyi z-d } \\
39 \text { (30). PLINFA Kharkiv } \\
40 \text { (45). Nizhyns'kyi z-d sil'hospmashyn [agricultural } \\
\text { machinery] } \\
41 \text { (43). Smilyans'kyi mashynobudivnyi z-d } \\
42 \text { (8). Novohrad-Volyns'kyi z-d sil'hospmashyn [agri- } \\
\text { cultural machinery] } \\
43 \text { (12). Chernihivs'kyi mekhanichnyi z-d } \\
44 \text { (48). Odes'kyi mashynobudivnyi z-d } \\
45 \text { (7). Zolotonis'kyi mashynobudivnyi z-d } \\
46 \text { (33). Kharkivs'kyi verstatobudivnyi z-d } \\
47 \text { (31). Eksperymental'no-mekhanichnyi z-d Poltava } \\
48 \text { (18). Konveier L'viv } \\
49 \text { (44). Il'nyts'kyi zavod } \\
50 \text { (28). Lebedyns'kyi z-d porshnevykh kilets' } \\
51 \text { (22). Khmel'nyts'kyi z-d Pryhma-Pres }\end{array}$ \\
\hline
\end{tabular}

1. Base no. - number in the ranked data series of decreasing average output (production value) in 2012-2016.

2. Rating no. - number in the ranked data series of decreasing VA indexes 2017 against 2012 (it is actual only for Fig. 1). 